\title{
The Effect of Guided Question Technique on Students' Writing Ability in Descriptive Text
}

\author{
Rizka Indriani \\ English Education Study Program, Department of Language and Art \\ University of Bengkulu \\ rizkaindriani41@yahoo.co.id \\ Zahrida \\ English Education Study Program, Department of Language and Art \\ University of Bengkulu \\ zahrida@yahoo.com \\ Mei Hardiah \\ English Education Study Program, Department of Language and Art \\ University of Bengkulu \\ mhardiah@unib.ac.id
}

\begin{abstract}
The objective of this research is to find out whether or not there is a significant effect using guided question technique on students' writing ability in descriptive text. This research is a quasi experimental design. The population of this research is the seventh grade students at SMPN 3 Kota Bengkulu. The sample in this research are about 60 students divided into 2 classes, VII 2 consists of 30 students as the experimental group and VII 3 that consist of 30 students as the control group. The treatment is given only for the experimental group. The data are collected by using two writing tests: pre-test and post-test. The result of the research showed the mean score of experimental group (31.34) was higher than mean score of control group (23.35). This indicated that the guided question technique could give a significant positive effect to the students' writing ability in descriptive text.
\end{abstract}

Key words : The Effect, Writing, Descriptive Text, Guided Question 


\begin{abstract}
ABSTRAK
Tujuan penelitian ini adalah untuk membuktikan ada tidaknya pengaruh teknik guided question terhadap kemampuan menulis siswa dalam teks descriptif. Penelitian ini menggunakan metode kuasi experimental. Populasi penelitian ini adalah siswa kelas 7 SMP N 3 Kota Bengkulu. Sampel dalam penelitian ini yaitu berjumlah 60 siswa yang terbagi menjadi 2 kelas, kelas VII 2 berjumlah 30 siswa sebagai kelas eksperimen dan kelas VII 3 berjumlah 30 siswa sebagai kelas kontrol. Perlakuan khusus hanya diberikan kepada kelas eksperimen. Data dikumpulkan dengan menggunakan dua tes: pre-test dan post-test. Hasil penelitian menunjukkan rata-rata skor kelompok eksperimen (31.34) lebih tinggi dibanding rata-rata skor kelompok kontrol (23.35). Hal ini mengindikasikan bahwa teknik guided question bisa memberikan pengaruh positif yang signifikan terhadap kemampuan menulis siswa.
\end{abstract}

\title{
Kata kunci: Efek, Menulis, Teks Descriptive, Guided Question
}

\section{INTRODUCTION}

Writing is one of the four integrated skills in English subject matter that should be learned by students in order to master English. It is one of the important skills for academic purpose. In writing, the students are demanded to transform their ideas into written form as an effect to communicate to the reader. This statement is supported by Nunan (2003) who stated that writing is the mental work of inventing ides, thinking about how to express them and organizing them into statements and paragraphs that will be clear to the reader. It can be concluded that writing skill is the ability that the students should have in order to express their ideas in written form.

Moreover, writing is not only about putting sentences together in correct grammar, but also the ideas in those sentences need to be organized in a logical way so that they can make a coherent text which easy for the reader to follow. That is why many students feel that writing is difficult. 
Based on the researcher's experience in teaching practice one of junior high school in Bengkulu City, the students still face some difficulties about writing. The first is lack of grammar understanding.

The second is the content or ideas about what to write. The last is organization of the ideas. There are still many students that do not know what they want to write but they do not know how to start it.

From the researcher's experience, it was also found out that students were difficult to develop their idea in writing, especially descriptive text. In school based curriculum of Junior High School for the seven grade, one type of texts that the students should achieve was descriptive text.

Aryanto (2009) argues that descriptive text is a text which describes a particular person, thing or place. Therefore, the people who read the descriptive tetxt will know the person, thing or place look like through the writing of the writer.

Due to the students' difficulty, they need guidance in writing descriptive text to make them easier in developing their ideas and also make their writing well organized. Therefore, there is a need to find a solution to solve the problem that the students face in the school. The use of guiding question technique in writing seems to be an appropriate technique to solve the problem. This is because guided question requires the students to write the test based on the set of question that is given by the teacher.

Guiding question technique is a technique which the students are guided to express their ideas into the written form by giving them some questions related to the topic (Traver, 1998). By guided question technique, the students are not confused of what to writee first and next because they have guidance in its process.

The questions are choosen as a technique to make the students' ability in understanding descriptive paragraph, for instance the teacher give the 


\section{Journal of English Education and Teaching \\ Volume 3 number 22019}

Pp. 216-229

question, the students answer the question and develop the idea in their writing. This technique provides a list of questions that can make the students think about the topic. Then, to give guidance about what should be included in students' writing.

Furthermore, descriptive text by using guiding question is one of good ways to teach English, Imanisa (2017) in her research entitle "Improving Students' Ability in Writing Descriptive Text through Guided Question Technique", showed that guided question technique improve the student's writing ability by increasing the students' grammatical, vocabulary and ideas. From this case the researcher know that guided question is a simple technique that brings an innovation in teaching, especially writing descriptive text.

Then, the design of this research was quasy experimental. The participants were 60 students who randomly selected. The instrument was writing test used in pretest and posttest. Pretest was conducted in order to find out the students' writing ability before the treatment. After conducting the treatment, the posttest was administered. It was done in order to know the students' ability after the treatment. The setting was at Junior High School Negeri 3 Kota Bengkulu especially at the seventh grade. After the data were collected, this study would analyze the effect of students; ability in writing descriptive text after the treatment. The data were scored by using scoring criteria for writing adapted from Brown (2007). They are content, organization, vocabulary choices, grammar and mechanics. After scoring students' work, the data were analyzed by using T-test to compare the data of two means score.

The t-test is use to know whether there is significant difference between experimental and control group. If the significant of $p$-value $<0,05$ it indicates that the Ho is rejected while $\mathrm{Ha}$ is accepted. Conversely, when the significant of $\mathrm{p}$-value $>0,05$, it shows that $\mathrm{Ho}$ is accepted and $\mathrm{Ha}$ is rejected. 


\section{Journal of English Education and Teaching \\ Volume 3 number 22019}

Pp. 216-229

Based on the problem faced by the students above, the reseacher is interested in doing a research in purposes to measure students' writing skill entitled "The Effect of Guided Question Technique on the Students' Writing Ability in Descriptive Text".

\section{LITERATURE REVIEW}

\section{Definition of Writing}

Writing is the most difficult skill, because it consists of complex, rhetorical and linguistic capabilities. Tarigan (2008), stated that in writing the writer should be able in using vocabulary, grammatical structure, and graphology. It means that writing needs full of attention and concetration both in grammatical structure and the organization of the text.

Writing is a skill which is used to express some ideas in written. According to Nunan (2003), a writers must have ideas which will be expressed through their writing. It means that in writing the students must have clear idea both in main ideas and supporting ideas which they want to write.

In addition, Ontario (2005) states that writing is powerful instrument for students to use to express their thoughts, feelings, and judgements about what they have read, seen, or experienced.compare to the other three skills, wtiting is considered to be the most difficult one to master. Therefore, Branan (2010) states that good writing is not only usually easy. Writing process challenges us all to overcome problems in our way.

From the definition above, it can be concluded that writing is the way of producing language and expressing ideas, feelings, and opinion in the form of letters, symbol, or words into written form. Writing is also distinguished as difficult skills, because it is complex process.

\section{Teaching of Writing}

Teaching writing to the learners is a job by the teacher. Teaching writing is not easy. It is a hard work. It is also added by Harmer (2003) the reason of 
teaching writing for the students of English as foreign language include reinforcement; language development, learning style and most important. It is important as to know how to write letter, how to put written report together, how to replay advertisement and increasing how to write electronic media.

In addition, Harmer (2003) adds teaching writing need consideration, which included the organization of sentence in paragraph join together. He added that coherent is the way to combine to join the sentence in paragraph.

Coffin (2003) states that in teaching writing, students writing in a response to a set assigment and to develop their own topic. The teacher gives the students a topic to write and then explore their ideas. The teacher asks the students follow the instruction that will make them be able to develop their ideas to write. The teacher explains the procedure of writing and then the students try to make their own.

Based on the statements above, it can be said that teaching writing is to train the students how to express the idea or imagination in written words.

\section{Descriptive Text}

Descriptive text is a part of factual genres (Wardiman el t al, 2008). It has social functionwhich is to describe a particular person, place, or thing. Descriptive gives sense impression like the feel, sound, taste and look of things through words. Its aim is also to inform the readers about how something or someone looks like. In descriptive text, the students also learn about generic structure.

The following generic structure of descriptive text by some experts. According to Wardiman (2008) the specify the generic structure of descriptive text into two parts : 1) introduction is the part of paragraph 
that introduces the character, 2) description is the part of paragraph that describes the character.

Therefore, descriptive text consist of two parts. First, the students must find general information. Second, the students must find specific information for example the characteristic of the students look. If the writer wants to write a descriptive text, they only need to go to the object or looking at a picture or watching a video, the take a note about thing.

In writing descriptive text, the writer must concer on the generic structure in order to make a good text.

\section{Guided Question Technique}

Guiding question technique is a technique which the students are guided to express their ideas into the written form by giving them some questions related to the topic (Traver,1998). The purpose of the questions is to give an easy way for the students to write descriptive paragraph which relates to the topic, in order to minimize the mistakes made by the students.

Langan (2005) states that one of the ways for writing is by giving the learned some questions as guidance before writing related to the topic, so that by answering the question the students can express their idea in writing easily and generately.

Taylor (2009) explains some steps in implementing guided questions as follows: First, choose the topic that will be written should be prepared by the students. Second, ask some question related yo the topic. Such as, what, who/whom, where, when, how, and why. Third, answer the questions which has been prepared based on their experience in form of outlining. Then, develop into paragraph, after the students get answer of the questions, guide them to develop the sentence into a paragraph. Last, final work, ask them to revise the paragraph and generate the organization based on the descriptive text and to re-write into a final draft. 
Pp. 216-229

\section{Advantages and Disadvantages of Guided Question}

\section{Advantages of guided question}

First, it can facilitate the teaching of writing to the students, so that the students will not be confused what they are going to write because they are guided to write by answering the questions related to the topic.

Second, it can make their writing more coherent because they write the paragraph by following the questions. Third, it can minimize mistakes by the students when they write. (Faiz,2011).

\section{Disadvantages of guided question}

This technique is difficult to be applied in guiding writing process in big group students because the class will be difficult to be controlled by the teacher. The teacher in writing a descriptive paragraph (Wulandari,2015).

\section{Previous Studies}

There are some relevant studies related to this research. The first study was conducted by Imanisa (2017) entitled "Improving Students' Ability in Writing Descriptive Text through Guided Question Technique at the second grade of SMPN 23 Bandar Lampung". In this research suggest that guided questions technique facilitates that the students to improve their writing ability. The second study was conducted by Genta (2017) entitled "The Effect of Guided Question Technique in Students' Writing Ability on Recount Text at eight grade of junior high school 30 Padang". This research showed that teching by using guided question technique gave improvement for students writing ability. The third study was conducted by Hariyanto (2018) entitled "The Influence of Using Guided Questions Technique Towards Students' Procedure Text Writing Ability". The 
conclusion of this research is guided question is effective to be used toward students' procedure text writing ability.

Based on the three previous studies, this research is different from the previous studies. First is location, location of this research is at SMPN 3 Kota Bengkulu. Second, the different can be seen from the subject, in this research the researcher take sample from seven grade of Junior High School, while other researches are from SMA, SMK and VIII grade.

\section{RESULT AND DISCUSSION}

\section{Result}

The present research was designed to find out the ability of the seventh grade of SMPN 3 Kota Bengkulu in writing descriptive text when they were taught by using guided questions technique and when they were taught writing without using guided questions technique. This research was done in 6 meetings each group, but 3 meetings taughts by teacher and 3 meetings by researcher. The researcher was administered pretest first, treatment, and posttest at the end of the research.

\begin{tabular}{|c|c|c|c|c|c|}
\hline $\begin{array}{c}\text { Post-Test } \\
\text { Group }\end{array}$ & $\begin{array}{c}\text { Mean } \\
\text { Score }\end{array}$ & T & Sig. (2-tailed) & $\begin{array}{c}\text { Mean } \\
\text { Difference }\end{array}$ & Conclusion \\
\hline Control & 23.35 & & & & \\
& & -5.394 & 0.000 & -7.99 & Significant \\
\hline Experimental & 31.34 & & & & \\
\hline
\end{tabular}

The result of the data can be seen from hypothesis testing by using independent sample t-test. Based on table, the result showed that the mean score of control group 23.35 and experimental group 31.34, Sig. (2- 
tailed) $0.00<0.05$, indicating that the two groups differ significantly, with mean difference was about -7.99. therefore, it can be concluded that both groups were significant difference, by seeing the mean score in the experimental group is better than the control group. In other words, students who are taught using guided questions technique gave improvement in writing ability descriptive text rather than students who are not taught using guided question technique.

\section{Discussion}

As a result, the research found that guided question technique had an effect or improvement on students' writing ability. It could be seen from the first aspect that improved was grammar. It happened because the teacher often repeated about sentences on Simple Present Tense such as the use of be (is,am,are). The same improvement with grammar is mechanic aspect.

It happened because the students followed the rule that the teacher asked like checking the right spelling of difficult words in the dictionary if they were not sure about the word that they had wrote. Besides, most of the students used correct marker in the sentences. Next aspect that improved was organization. It happened because by the following questions, the students could write descriptive text coherently. The transactional signal made together with the questions were also very helpful the students to make their descriptive paragraph coherent. Then, content aspect make the students can develop the supporting sentences in the organization of text effectively. They seldom wrote the supporting sentence out to the topic sentence. While the last aspect that improved after applying guiding question technique was vocabulary. The students were able to find the appropriate vocabulary with the context. 


\section{Journal of English Education and Teaching \\ Volume 3 number 22019}

Pp. 216-229

On the other hand, by using guided question technique, the students can learn more effective and efficient because of students more active in the teaching process and it makes the students easier to understand the material that will be given. Meyers (2005) said that question can be way to help exploring topic in writing skill.

Therefore, giving questions to the students is expected to stimulate students' thoughts and they can compose the paragraph by answering the questions given to them.

Supported by several researchers, Genta (2017) conducted a research to find out whether guided questions technique gave significant effect towards students' writing ability on recount text at eight grade.

Similarly, in this research the result are giving significant positive effect to the students writing ability. In addition, using guided question technique make an attracting an enjoyable activity for improving writing skill and puts it on the students to investigate the questions and find answer they can apply in their everyday lives. It also found it Genta that guided question technique was effective to improve students writing ability in recount text and got positive responses from students.

Furthermore, Rivers (1964) also supported this idea by saying " a series of questions may be constructed that the students write continues story as they answer the questions". Based on the statement from River, the treatment was did by applying guiding question technique to help or guide the students to write a descriptive paragraph easily. This means that, when the teacher asks the questions, it will make the students open their brain to create their ideas. Therefore, guided question technique not only helps the students in generate, sort, arrange and organize ideas to be developed their writing but also it motivates the students to produce better writing.

Reffering to the explanations above, it can be concluded that guiding question technique is a good technique to be applied in teaching 


\section{Journal of English Education and Teaching \\ Volume 3 number 22019}

Pp. 216-229

descriptive text. Through guiding question technique, the students are able to develop their ideas in a well-organized way. It was proven by the improvement of total mean score of the test before and after the treatment.

\section{CONCLUSION AND SUGGESTION}

\section{Conclusion}

Based on the results and discussion at the research, it can be concluded that teaching writing descriptive text by using guided question technique has a positive effect on students' writing ability, especially in writing descriptive text. It can be seen by the result of posttest that the mean score of control and experimental group got higher score than control group.

Therefore, guided question technique has been successfully implemented as an interesting technique to improve students' writing ability. In addition, it can affect students' writing skill in term of content, organization, grammar, vocabulary and mechanics.

\section{Suggestion}

There are some suggestions are proposed as follows:

1. For students

Students are suggested to write more by applying the guided question technique so they will be more skillful in writing.

2. For teachers

Teachers are suggested to be more creative and innovative in using various kinds of interesting teaching technique which accompany the materials, so that the students will be more active and encouraged to learn in the class.

3. For researcher 
For researchers who are interested in conducting the research more detail about the effect of using guided question technique for teaching writing, the researcher hopes that the research findings can be used as a starting point of the future researchers who have the same problems and this research can be utilized as reference. 


\section{REFERENCES}

Aryanto, S. (2009). Descriptive texts ( Panduan menulis teks deskriptif). Bandung: Pakar Raya.

Branan, B. (2010). A Writer's Workshop: Crafting Sentences, Building Paragraphs. New York: McGraw-Hill.

Brown, H. Douglas. (2007). Teaching by Principles: An Interactive Approach to Language Pedagogy. New York: Longman.

Coffin, C. (2003). Teaching academic writing: A toolkit for higher education. London and New York: Routledge.

Faiz, M. (2011). The Use of Guiding Question Technique to Improve Students' Descriptive Text. Walisongo State Islamic University.

Genta. (2017) : The Effect of Guided Questions Technique in Sudents' Writing Abilty on Recount Text at Eighth Grade of SMP N 30 Padang. UIN Imam Bonjol Padang.

Hammer, Jeremy. (2003). The practice of English Language Teaching, England: Longman.

Hariyanto. (2018). The Influence of Using Guided Questions Technique Towards Students' Procedure Text Writing Ability. English Education, Lampung University, Indonesia. IOSR Journal of Research \& Method in Education (IOSR-JRME) , vol. 8, no. 4, 2018, pp. 77-82.

Imanisa, Sahaja Talenta. (2017). Improving Students' Ability in Writing Descriptive Text through Guided Question Technique at the second grade of SMPN Negeri 23 Bandar Lampung. University of lampung.

Langan, John. (2005). College Writing Skill. New york: The McGraw Hill Companies,Inc.

Meyers, Alan. (2005). Gateways to Academic Writing. New York: Longman.

Nunan, David. (2003). Practical English Language Teaching. Singapore: Mc Graw-Hill Company.

Ontario. (2005). A Guide to Effective Instruction in Writing. Toronto: Ontario Education.

Rivers, W. M. (1964). Teaching foreign language skill. Chicago: The University of Chicago.

Tarigan, H. G. (2008). Menulis Sebagai Suatu Keterampilan Berbahasa. Bandung: Angkasa Bandung.

Taylor, G. (2009). A student's writing guide: how to plan and write sucessful essays. New York: Cambridge University Press.

Traver, R. (1998). What is a good guiding question? Educational Leadership, 55 (6), 70-73.

Wardiman, et, al., (2008). English in Focus for Grade VII Junior High School (SMP/MTS ), Jakarta: Pusat Perbukuan Depdiknas.

Wulandari, (2015). Improving Students' Ability In Writing Descriptive Paragraph Through Guiding Questions Technique At The Second Grade Of Smpn 1 Gadingrejo Pringsewu. University of Lampung. 